\title{
$\frac{100}{\mathrm{WiT}}$ RPESS
}

\section{CZASOPISMA PRAWNOROLNE W POLSCE. REFLEKSJE NA TLE PERIODYKÓW ZACHODNIOEUROPEJSKICH}

I. Prawo rolne jako jedna ze szczegółowych nauk prawnych nie ma takiej tradycji jak prawo cywile, karne czy administracyjne. Nie można jej dziśs sprowadzać, jak w przeszłości, do problematyki gospodarki gruntami rolnymi i organizacji produkcji rolnej. Współczesny kształt tej nauki w Polsce determinuje objęcie naszego rolnictwa mechanizmami wspólnej polityki rolnej. Polityka ta wpływa na rozwój ustawodawstwa dotyczącego rolnictwa i powoduje coraz większą „złożoność prawa rolnego"1 jako gałęzi prawa. Z tego choćby względu uzasadnione jest funkcjonowanie na rynku wydawniczym czasopism prawnorolnych, które by, z jednej strony, wspierały rozwój nauki prawa rolnego, a z drugiej - służyły praktyce stanowienia i stosowania prawa.

Czasopisma prawnorolne w Polsce były tworzone znacznie później niż periodyki z tej dyscypliny w państwach zachodnioeuropejskich. Te ostatnie maja już utrwalone miejsce w czasopiśmiennictwie prawniczym, świadczą o stopniu rozwoju nauki prawa rolnego i jej użyteczności praktycznej. Celem niniejszych rozważań jest sformułowanie oceny czasopism prawnorolnych w Polsce właśnie na tle periodyków zachodnioeuropejskich. W szczególności ocena ta ma na uwadze misję czasopisma, zakres tematyczny, układ treści i język publikacji oraz krag ich adresatów-czytelników. Ze względu na okres funkcjonowania na rynku wydawniczym oraz dorobek publikacyjny w pierwszej kolejności uwzględnia się doświadczenia włoskie, a następnie niemieckie, francuskie i hiszpańskie.

II. Rozpoczęcie prezentacji zachodnioeuropejskich czasopism naukowych z zakresu prawa rolnego od włoskiego kwartalnika „Rivista di Diritto Agra-

\footnotetext{
* Roman Budzinowski, Uniwersytet im. Adama Mickiewicza w Poznaniu, romanb@amu.edu.pl, https://orcid.org/0000-0003-4218-3143, Redaktor naczelny czasopisma „Przegląd Prawa Rolnego”.

1 Wyrażenie Bootha (2020): 321.
} 
rio" uzasadnia wiele względów. Nie chodzi tylko o argumenty historyczne w przyszłym roku minie sto lat od jego założenia. Ważniejsze bowiem jest stwierdzenie, że legło ono u podstaw wyodrębnienia i rozwoju nowej dziedziny prawa, a niemal stuletni nieprzerwany okres obecności na rynku wydawniczym przyczynił się do umocnienia pozycji nauki o tym prawie wśród innych szczegółowych dyscyplin prawoznawstwa. Nie dziwi więc, że historia czasopisma i jego wkład w rozwój nauki prawa rolnego (i nauk prawnych w ogóle) stały się, z okazji kolejnych rocznic, przedmiotem licznych publikacji ${ }^{2}$. Już choćby $\mathrm{z}$ tego względu warto poświęcić mu nieco więcej miejsca.

Na początku XX w. we Włoszech znacznie wzrosła ingerencja publiczna dotycząca rolnictwa. Pojawiły się specjalne regulacje tego działu gospodarki, które wprowadzały instytucje i zasady prawa publicznego w zakresie spraw tradycyjnie zarezerwowanych dla autonomii właściciela ${ }^{3}$. Nowe unormowania, których nie sposób było traktować jako wyjątkowe, oddalały tę dziedzinę regulacji od prawa cywilnego, a jednocześnie rodziły wiele problemów w praktyce. Wychodząc naprzeciw potrzebom „świata rolniczego”, Giangastone Bolla na początku 1922 r. założył prezentowane tu czasopismo, którego tytuł zawierał jeszcze nierozpowszechnioną w obiegu naukowym nazwę nowej dziedziny prawa, właśnie „prawo rolne” (diritto agrario). Ukazujące się do tego czasu publikacje, także periodyczne, z reguły dotyczyły tylko niektórych aspektów legislacji rolnej ${ }^{4}$.

Należało więc, zgodnie z opublikowanym Programem, utworzyć periodyk poświęcony ustawodawstwu i orzecznictwu rolnemu, gdyż nie do pomyślenia było, by we Włoszech, kraju wybitnie rolniczym, nie funkcjonowało takie czasopismo prawnicze. Rolnicy coraz silniej odczuwali potrzebę znajomości bardzo licznych ustaw oraz orzeczeń, które ich dotyczyły, zwłaszcza że obok gruntu (fondo) przedmiotem regulacji, coraz bardziej intensywnej, stawało się gospodarstwo rolne (azienda agraria) rozumiane jako centrum działalności gospodarczej i społecznej ${ }^{5}$. Czasopismo natomiast zakładało istnienie nowej materii normatywnej dotyczącej rolnictwa, nazwanej prawem rolnym.

Zainspirowało ono podjęcie problematyki autonomii tego prawa. Była to w latach dwudziestych i trzydziestych ubiegłego wieku czołowa kwestia teoretyczna i temat licznych artykułów publikowanych w tym okresie. Głos zabierali znakomici autorzy, używając różnych argumentów. Okazało się, że rezultaty tej dyskusji znacznie wykroczyły poza oczekiwania twórcy czasopisma. Prawo rolne już w okresie międzywojnia uzyskało autonomię dydaktyczną; stało się przedmiotem nauczania na studiach wyższych, a także specjalnością naukową badaczy ${ }^{6}$. Natomiast rozważanie kwestii autonomii naukowej było,

${ }^{2}$ Zob. np. Romagnoli (1972): 1 n.; Sirsi (1986): 420 n.; Trebeschi (2011): 242 n.; Cristiani (2008): 464 n.; Germanò (2017).

${ }^{3}$ Tak Giorgianni (1964): $21 \mathrm{n}$.

${ }^{4}$ Bliżej Trebeschi (2011): 242 przyp. 2.

${ }^{5}$ Fragmenty programu powołane za: Germanò (2017): 8-9.

${ }^{6}$ Germanò (2017): 14 przyp. 2. O prawie rolnym i jego nauczaniu w różnych ośrodkach naukowych zob. Trebeschi (2011): 245. 
jak się ocenia ${ }^{7}$, siłą napędową dyskusji nad wypracowaniem „prawa właściwego dla rolnictwa”, przyczyniło się do nowoczesnego ujęcia tego działu gospodarki w kodeksie cywilnym z $1942 \mathrm{r}^{8}$

W rezultacie na łamach czasopisma „antyczne kontrowersje wokół autonomii" zostały zastapione przez debatę merytoryczna. Autorzy rozważali niezmiernie istotne problemy związane $\mathrm{z}$ rozwojem ustawodawstwa rolnego, rozszerzaniem się przedmiotu regulacji i kształtowaniem nowych granic, a jednocześnie rozstrzygali trudne problemy interpretacyjne, odpowiadając w ten sposób na potrzeby praktyki stosowania prawa ${ }^{9}$. Zawsze, na początku zwłaszcza dzięki zagranicznym kontaktom naukowym Bolla, były (i są do dzisiaj) publikowane artykuły z zakresu prawa porównawczego ${ }^{10}$, a autorzy spoza Włoch (i to z wielu kontynentów) mają możliwość ogłaszania efektów swoich badań nie tylko w języku włoskim, ale także w języku angielskim, francuskim czy w hiszpańskim.

W coraz szerszym zakresie były podejmowane problemy zwiąane ze wspólnotowym, a później unijnym prawem rolnym. Efekt tych badań znalazł między innymi wyraz w licznych artykułach odnotowujących znaczenie kwestii środowiskowych w działalności rolniczej, narastanie prawa rolno-środowiskowego ${ }^{11}$. Nieco później, zwłaszcza na początku obecnego wieku, dzięki prawu unijnemu została dowartościowana problematyka żywnościowa związana z rozwojem regulacji prawnych dotyczących bezpieczeństwa żywnościowego oraz bezpieczeństwa i jakości żywności ${ }^{12}$. Reakcją redakcji czasopisma na zmiany ustawodawstwa było dodanie w 2005 r. podtytułu „Agricoltura, Alimentazione Ambiente” [„Rolnictwo, Wyżywienie, Środowisko”]. Odzwierciedla on współczesne tendencje rozwoju prawa rolnego (ekspansję jego przedmiotu), a jednocześnie daje wyraz jedności regulacji prawnych odnoszaccych się do rolnictwa. Problematyka rolno-środowiskowa i rolno-żywnościowa to przedmiot bardzo licznych artykułów publikowanych w czasopiśmie.

Przez wiele dziesięcioleci „Rivista di Diritto Agrario” było wydawane przez Istituto di Diritto Agrario Internazionele e Comparato (IDAIC) we Florencji ${ }^{13}$. Po likwidacji tego Instytutu w 2017 r. rolę wydawcy przejęła Sekcja Florencka Międzynarodowego Prawa Rolnego i Porównawczego przy Instytucie Międzynarodowych Studiów Prawnych. Nie zmieniła się natomiast struktura czasopisma. Każdy zeszyt podzielony jest na dwie części. Pierwsza część (dottrina) zawiera artykuły, również autorów zagranicznych, dotyczące najbardziej aktualnych problemów prawnej regulacji rolnictwa, ujęte w ramach wyodrębnio-

7 Tak Carrozza (2001): 691.

${ }^{8}$ Costato, Casadei (2000): 4.

${ }^{9}$ Por. Irti (1977): 479-480.

${ }^{10} \mathrm{~W}$ niektórych zeszytach problematyka prawnoporównawcza jest bardzo znacząca. Zob. np. zeszyt poświęcony pojęciu gospodarstwa rolnego w różnych porządkach prawnych („Rivista di Diritto Agrario" 1954, z. 3), a w innych publikowane są artykuły dotyczące, dla przykładu, konstytucyjnych aspektów prawa rolnego (,Rivista di Diritto Agrario” 1985, z. 1) czy instalacji młodych rolników („Rivista di Diritto Agrario” 1986, z. 4).

${ }_{11}$ Zob. np. Costato (1987): 146 n.; D’Addezio (1999): 176 n.; Galloni (2000): 402 n.

${ }^{12}$ Zob. np. Ballarin Marcial (1984): 208 n.; Carrozza (1986): 70 n.; Costato (2003): 324 n.

${ }^{13} \mathrm{Z}$ wyłączeniem okresu, gdy stanowiło ono własność założyciela, prof. Bolla. 
nych w spisie treści działów, jak np.: studia, badania i dokumentacja, dydaktyka, włoskie ustawodawstwo rolne, recenzje i noty recenzyjne, czy przegląd literatury agrarystycznej. Część druga o mniejszej objętości (giurisprudenza) obejmuje komentarze do orzeczeń sądowych, a także sprawozdania, informacje i debaty.

Niewątpliwie „Rivista di Diritto Agrario” jest najbardziej znanym i uznanym czasopismem z zakresu prawa rolnego o międzynarodowej renomie. Publikowane w nim artykuły nie są jedynie formą rejestracji najważniejszych problemów ustawodawstwa rolnego i próbą ich rozstrzygnięcia. Przedmiotem dyskursu naukowego są także innowacyjne tematy, odpowiadajace współczesnym wyzwaniom prawa rolnego na poziomie krajowym i unijnym, a również zagadnienia o wymiarze globalnym ${ }^{14}$. Ich zestawienie daje wyraz tendencjom rozwoju prawa rolnego i kształtowania się nauki o tym prawie. Dobór autorów z różnych państw, jak też stopień zorganizowania obecnego wydawcy - Sekcji Florenckiej Międzynarodowego Prawa Rolnego i Porównawczego - pozwala podzielić optymistyczny pogląd Alberta Germanò o przygotowaniu i wydaniu setnego i kolejnych roczników czasopisma ${ }^{15}$.

Gwoli ścisłości należy odnotować, że na rynku wydawniczym we Włoszech funkcjonowało i nadal jest wydawanych wiele czasopism prawnorolnych ${ }^{16}$. Warto wymienić „Agricoltura Istituzioni Mercati”, kwartalnik założony w 2004 r. i publikowany przez Uniwersytet w Maceracie. Wprawdzie ostatni numer ukazał się w 2018 r., ale to na łamach tego czasopisma były podejmowane niezmiernie trudne, a przy tym nowatorskie tematy, zarysowane we wstępnym, programowym artykule założyciela Francesca Adornato $O$ czym mówimy, gdy mówimy o rolnictwie $e^{17}$.

Znacznie dłuższą, sięgającą bowiem lat pięćdziesiątych, tradycję ma czasopismo, które od 2006 r. występuje pod nazwą „Diritto e Giurisprudenza Agraria, Alimentare e dell'Ambiente". Zawiera ono artykuły dotyczące różnych aspektów prawa rolnego, żywnościowego i środowiskowego, ale przede wszystkim komentarze do orzeczeń sądowych. Są w nim uwzględniane, ze względu na obecnego wydawcę $e^{18}$, także aspekty prawnokarne. Jest to czasopismo (dwumiesięcznik), które ukazuje się tylko w wersji online z bezpłatnym dostępem. Coraz większym uznaniem cieszy się, wydawany od kilku lat, kwartalnik poświęcony prawu rolno-żywnościowemu („Diritto Agroalimentare”). Na jego łamach autorzy (także zagraniczni) podejmują tematy, które nie tylko sa doniosłe $\mathrm{z}$ teoretycznego punktu widzenia, ale mają także istotne znaczenie praktyczne ${ }^{19}$.

14 Zob. np. Alabrese (2016): 210 n.; Bolognini (2018): 110 n.

15 Germanò (2017): 94.

16 Omawia je Cristiani (2008): $464 \mathrm{n}$.

17 Adornato (2004): $5 \mathrm{n}$.

18 Od stycznia 2015 r. wydawcą jest Fundacja „Obserwatorium Przestępczości w Rolnictwie i Systemie Rolno-żywnościowym” (Fondazione „Osservatorio sulla Criminalità nell’Agricoltura e sul Sistema Agroalimentare”).

19 Zob. np. Goldoni (2019): 19 n.; Jannarelli (2020): 309 n. 
Z kolei w Niemczech czołowym czasopismem z zakresu prawa rolnego jest „Agrar- und Umweltrecht” (AUR). Wrześniowy, dziewiąty numer z 2020 r. zawiera okolicznościowe publikacje z okazji jubileuszu pięćdziesięciolecia. Nie było ono wprawdzie pierwszym periodykiem z tej dziedziny prawa ani nie inicjowało dyskusji na temat jej wyodrębnienia ${ }^{20}$. Założyciele zmierzali do wzmocnienia pozycji prawa rolnego i upowszechnienia jego znajomości. „Prawa rolnego nie można na dalszą metę zepchnąc na dalszy plan”, jak napisał w przedmowie do pierwszego numeru ówczesny przewodniczący Niemieckiego Towarzystwa Prawa Rolnego (Deutsche Gesellschaft für Agrarrecht DGAR) ${ }^{21}$. To Towarzystwo do dziś jest wydawcą tego czasopisma ${ }^{22}$.

W okresie minionych pięćdziesięciu lat, dzięki publikacjom zarówno teoretyków, jak i praktyków (zwłaszcza adwokatów), AUR z powodzeniem realizował swoją misję. Obok typowych tematów z zakresu prawa krajowego (np. dzierżawy gruntów rolnych, scalania gruntów, prawa spadkowego, leśnego, czy ubezpieczeń społecznych) w coraz szerszym zakresie podejmowano nowe problemy związane z rozwojem ustawodawstwa, w ramach których istotne miejsce przypadało wdrażaniu prawa wspólnotowego (unijnego) ${ }^{23}$. Efektem docenienia potrzeby ochrony środowiska w rolnictwie i roli prawa w tym zakresie była zmiana nazwy czasopisma - pierwotny tytuł „Agrarrecht” został w 2003 r. zastapiony przez „Agrar- und Umweltrecht”24.

Informacja zamieszczona w podtytule wskazuje, że czasopismo poświęcone jest „całemu prawu rolnictwa, rynków rolnych oraz obszarów wiejskich”. Ukazuje się ono co miesiąc i zawiera kompleksowy przegląd stanu wiedzy, orzecznictwa i praktyki w zakresie prawa rolnego. Obok opracowań o charakterze artykułowym bardzo szeroko prezentowane i komentowane jest orzecznictwo w sprawach rolnych. Z tego względu ten periodyk spełnia istotną rolę w upowszechnieniu znajomości problematyki prawnorolnej, odpowiada także na potrzeby praktyków. Dzięki temu czasopismu, jak się uważa, prawo rolne nie tylko nie zostało ,zepchnięte na dalszy plan”, ale stało się przedmiotem szerszej debaty społeczno-politycznej ${ }^{25}$.

Odpowiednikiem prezentowanego tu periodyku niemieckiego jest francuski „Revue de Droit Rural”. W bieżącym roku jubileuszowym (50-lecie założenia) zostanie wydany pięćsetny numer. Na łamach tego czasopisma publikowane są zarówno artykuły ważne dla rozwoju nauki prawa rolnego, jak i dla praktyki jego stosowania. Zakres tematyczny jest bardzo szeroki - od kwestii związanych, przykładowo, ze strukturami rolnymi, dzierżawa gruntów rolnych, organizacją produkcji, rynkami rolnymi, podatkami po ochronę

${ }^{20}$ Wcześniej ukazywało się między innymi czasopismo „Recht der Landwirtschaft”. To na jego łamach Karl Kroeschel opublikował artykuł dotyczący teoretycznych podstaw prawa rolnego: Was ist Agrarrecht? (Kroeschel 1965: 277 n.).

21 Booth (2020): 321.

22 Siedzibą redakcji czasopisma jest Institut für Landwirtschaftsrecht Uniwersytetu w Getyndze.

${ }^{23}$ Zob. np. Martínez (2010): 216 n.; Busse (2015): 321 n.; Krüger, List (2017): 41 n.

24 Nies (2020): 323.

25 Both (2020): 321. 
środowiska w rolnictwie, ochronę zwierząt, rozwój obszarów wiejskich czy bezpieczeństwo żywności ${ }^{26}$. Wiele miejsca poświęca się wspólnej polityce rolnej i unijnemu prawu rolnemu ${ }^{27}$. Rzadziej natomiast publikowane sa artykuły dotyczące teoretycznych zagadnień prawa rolnego ${ }^{28}$.

Dodany i rozbudowany podtytuł wskazuje, że czasopismo obejmuje problematykę rolnictwa, sektora rolno-żywnościowego, obszarów wiejskich oraz środowiska. Układ treści od wielu lat jest stały: w pierwszej kolejności publikowane sa krótkie noty na tematy bieżące oraz artykuły, a następnie - jest to część najbardziej rozbudowana - komentarze do orzeczeń ułożone według pewnego schematu (np. dzierżawa rolnicza, SAFER, obszary wiejskie, środowisko, rolne prawo socjalne, organizacja produkcji i rynków, spółdzielnie czy prawo Unii Europejskiej. Już układ treści wskazuje, że dominują w nim opracowania z zakresu praktyki stosowania prawa. Czasopismo ukierunkowane jest przede wszystkim na zaspokojenie potrzeb „świata rolniczego”. Nie dziwi więc jego olbrzymi nakład (1800 egzemplarzy).

Natomiast hiszpański periodyk „Revista de Derecho Agrario y Alimentario” bliższy jest, z punktu widzenia charakteru, włoskiej „Rivista di Diritto Agrario". Powstał on w 1985 r., a więc w roku poprzedzającym przyjęcie Hiszpanii do Europejskiej Wspólnoty Gospodarczej i objęcie tego kraju wspólną polityką rolną. Założycielem czasopisma był Alberto Ballarín Marcial, osoba niezwykle zasłużona dla rozwoju nauki prawa rolnego i współpracy międzynarodowej w tym zakresie. W artykule otwierającym pierwszy numer z 1985 r. pokazał on związki prawa rolnego z prawem żywnościowym, zwane dziś łańcuchem żywnościowym ${ }^{29}$. Tłumaczą one tytuł czasopisma, odwołujący się do prawa rolnego i prawa żywnościowego. Nieco później doszło spostrzeżenie, że prawo rolne, pełniąc rolę integratora, musi obejmować także problematykę tzw. świata wiejskiego oraz środowiska ${ }^{30}$.

Krag czytelników został określony bardzo szeroko - to zarówno badacze zajmujący się prawem rolnym, jak i przedstawiciele praktyki stosowania prawa, w tym administracji rolnictwa, stowarzyszeń rolniczych i zawodowych, to jest specjaliści zajmujący się z racji wykonywanej profesji problematyka rolnictwa, żywności i środowiska. Z tego też względu zakres przedmiotowy artykułów uległ z biegiem czasu znacznemu rozszerzeniu. Zawsze była obecna problematyka związana z prawem wspólnotowym i unijnym. Zwracają uwagę opracowania podejmujace istotne problemy teoretyczne prawa rolnego, także w skali globalnej ${ }^{31}$, a jednocześnie publikacje służące rozwiązywaniu konkretnych problemów występujących w praktyce ${ }^{32}$. W tym półroczniku dominuja studia doktrynalne, ale prezentowane są także zmiany legislacyjne, orzecz-

\footnotetext{
${ }^{26}$ Zob. np. Peignot (2016): 13 n.; Abramowitch (2016): 19 n.

27 Zob. np. Gadbin (2012): 1-2; Blumann (2013): 17 n.

28 Zob. np. Foyer (2010): 1-2; (2012): 1-2.

29 Ballarin Marcial (1985): $7 \mathrm{n}$.

30 De la Cuesta Sáenz (2016): 10.

31 Zob. np. Sánchez Hernández (2000): 19 n.; Gil Adrados (2016): 79 n.

32 Zob. np. Bourges (2015): 51 n.; Cosialls Ubach (2017): 83 n.
} 
nictwo oraz przegląd literatury. Czasopismo jest wydawane przy współpracy z Hiszpańskim Stowarzyszeniem Prawa Rolnego.

Wprawdzie przegląd czasopism prawnorolnych został już w tytule ograniczony do państw zachodnioeuropejskich, ale warto przynajmniej zaznaczyć, że periodyki z tego zakresu wydawane są w innych państwach, także pozaeuropejskich. Od 2013 r. publikowane jest przez Uniwersytet Przyrodniczy w Nitrze „EU Agrarian Law”, jedyne na Słowacji czasopismo z zakresu prawa rolnego. Ukazuje się ono online w otwartym dostępie jako półrocznik w języku angielskim. Od 2015 r. Europejski Komitet Prawa Rolnego wydaje „CEDR Journal of Rural Law”, półrocznik, czasopismo w otwartym dostępie zawierające informacje o działalności Komitetu, a także artykuły naukowe w wielu językach (preferowany angielski, francuski i niemiecki), dotyczące problemów globalnych, unijnego prawa rolnego i systemów prawnych różnych państw ${ }^{33}$.

Wiele czasopism z zakresu prawa rolnego wydają różne ośrodki naukowe w Stanach Zjednoczonych Ameryki Północnej. Do najbardziej znanych należy, założony w 1996 r., „Drake Journal of Agricultural Law”. Stanowi on forum służące pogłębianiu problematyki z zakresu międzynarodowego i krajowego prawa rolnego, zapewniające pewną równowagę między treścią akademicka i praktyczną. Opracowania publikowane w starszych rocznikach (do 2017 r.) dostępne są online. Odnotować należy także czasopismo „Revista Iberoamericana de Derecho Agrario", wydawane wprawdzie w Argentynie, ale skupiające agrarystów z wielu państw, zwłaszcza Ameryki Południowej. Zawiera ono artykuły (w części zwanej doktryna) poruszające różne problemy z zakresu prawa rolnego, a także komentarze do orzeczeń, przeglądy orzecznictwa oraz legislacji.

III. Czasopisma prawnorolne w Polsce nie maja tak długiej tradycji, jak zaprezentowane periodyki z państw zachodnioeuropejskich. Na rynku wydawniczym pojawiły się dopiero w latach dziewięćdziesiątych ubiegłego wie$\mathrm{ku}$, w okresie szczególnie trudnym dla rozwoju nauki prawa rolnego. Zmiana ustroju społeczno-gospodarczego spowodowała po 1989 r. pewne osłabienie rangi prawa rolnego, będące konsekwencją znacznego ograniczenia dotychczasowego ustawodawstwa rolnego ze względu na wprowadzenie gospodarki rynkowej. Znalazło ono również pewne odbicie w sferze nauczania, jak też w obszarze aktywności badawczej, która uległa przejściowemu osłabieniu ${ }^{34}$. Na tym tle należy w kategoriach sukcesu odnotować powołanie do życia czasopisma „Prawo Rolne”, poprzedzone wydaniem w latach 1979-1989 siedmiu tomów rocznika „Zagadnienia Ustroju Prawnego Rolnictwa”.

W 1990 r. zostało zorganizowane Polskie Towarzystwo Prawa Rolnego, które podjęło decyzję o wydawaniu kwartalnika z zakresu prawa rolnego. Inicjatorem tych przedsięwzięć był Marian Błażejczyk, kierujący do 1993 r. Zespołem Ustroju Wsi i Prawa Rolnego INP PAN w Warszawie ${ }^{35}$. Pierwszy ze-

${ }^{33}$ Zob. np. Spoto (2019): 9 n.; Mögele, Rusu (2018): 9 n.; Paiva Pereira (2015): 98 n.

34 Bliżej: Budzinowski (2012): 19 n.

35 Bliżej: Paliwoda (1996): 21. 
szyt nowego czasopisma ukazał się jeszcze w 1991 r. nakładem, utworzonego również z inspiracji prof. Błażejczyka, Instytutu Reformy i Integracji Rolnictwa ze Wspólnotą Europejską. Nowością był udział w Komitecie Redakcyjnym bardzo licznych, uznanych agrarystów zagranicznych, także spoza Europy, jak też powoływanie się na współpracę przy jego wydawaniu z wieloma zagranicznymi instytutami oraz stowarzyszeniami prawa rolnego.

Od początku czasopismo obejmowało takie działy, jak doktryna, rolnicze prawo stosowane, prawo w gminie i w sołectwie oraz orzecznictwo, a ponadto zawierało ekspertyzy, teksty aktów prawnych, czy ich projektów, kronikę ważniejszych wydarzeń oraz sylwetki koryfeuszy prawa rolnego. Układ treści świadczył o tym, że redakcja dużą wagę przywiązuje nie tylko do rozwoju nauki prawa rolnego, lecz także do rozwiązywania problemów występujących w praktyce jego stosowania. Niewątpliwie doniosłe z poznawczego oraz teoretycznego punktu widzenia były artykuły dotyczące wspólnotowego prawa rolnego oraz przyszłej europejskiej integracji polskiego rolnictwa ${ }^{36}$. Publikacja w języku polskim opracowań uznanych agrarystów zagranicznych przybliżała polskiemu czytelnikowi istotne problemy prawa rolnego $\mathrm{w}$ innych systemach prawnych $^{37}$.

Z pewnościa prezentowane tu czasopismo było „nie kwestionowanym najważniejszym w kraju forum wymiany myśli naukowej w dziedzinie światowej nauki prawa rolnego oraz jej trendów rozwojowych"38. Należy także odnotować, że Błażejczyk założył również periodyk „Izby Rolnicze”, wydawany w latach 1997-1998. Jego ostatnią inicjatywę edytorską stanowił rocznik „Acta Iuridica Agraria”, którego pierwszy wolumen został opublikowany w 1999 r. również nakładem Instytutu Reformy i Prawnej Integracji Rolnictwa ze Wspólnotą Europejska. Zamiarem fundatora było utworzenie naukowego organu publikacyjnego Europejskiej Grupy Regionalnej Światowego Związku Agrarystów Uniwersyteckich - UMAU. Z tego względu dominowały w nim artykuły uznanych agrarystów z różnych państw ${ }^{39}$. Wypada docenić tę pionierską próbę umiędzynarodowienia nauki prawa rolnego. Jednakże słabością tej i poprzednich inicjatyw wydawniczych był zbyt waski krag autorów, ograniczony w dużej mierze - zwłaszcza w odniesieniu do dwóch pierwszych czasopism - do współpracowników prof. Błażejczyka.

Gdy chodzi o czasy współczesne, należy bliżej scharakteryzować dwa czasopisma. Pierwszym były „Studia Iuridica Agraria”. Na zjeździe katedr i zakładów prawa rolnego w Rajgrodzie w 1997 r. zostało założone Polskie Stowarzyszenie Prawników Agrarystów ${ }^{40}$. Publikacja, której inauguracyjny tom ukazał się w 2000 r. jeszcze jako praca zbiorowa, miała być właśnie periodykiem wydawanym staraniem tego Stowarzyszenia. Ono bowiem, z racji skupienia agrarystów z różnych ośrodków naukowych, dawało gwarancję sys-

${ }^{36}$ Zob. np. Błażejczyk (1991): 5 n.; (1993): 5 n.

37 Zob. np. Hudault (1991): 19 n.; Costato (1996): 23 n.

38 Paliwoda (1996): 21.

39 Zob. np. Brebbia (1999): 45 n.; Orlando (1999): 113 n.

${ }^{40}$ Wpisane jeszcze w listopadzie tego samego roku do rejestru Stowarzyszeń. Zob. Prutis (1998): 296. 
tematycznego wydawania kolejnych tomów w cyklu rocznym lub dwuletnim, gdyż zapewniało szeroki krąg autorów, zarówno uznanych autorytetów, jak i młodych adeptów prawa rolnego ${ }^{41}$. Pierwsza część publikacji poświęcona była uroczystości nadania doktoratu honoris causa Uniwersytetu Białostockiego prof. Andrzejowi Stelmachowskiemu, twórcy naukowej szkoły prawa rolnego i pierwszemu przewodniczącemu Zarządu wspomnianego Stowarzyszenia, natomiast druga zawierała artykuły dotyczące różnych merytorycznych problemów prawa rolnego oraz jedną recenzję.

Bardzo pozytywne przyjęcie tej pracy zbiorowej, jak też wspomniana potrzeba posiadania przez środowisko agrarystów własnego organu publikacyjnego sprawiły, że kolejny tom ukazał się już jako czasopismo zarejestrowane rocznik Polskiego Stowarzyszenia Prawników Agrarystów. Funkcja redaktora naczelnego została powierzona Stanisławowi Prutisowi, ówczesnemu dziekanowi Wydziału Prawa i Administracji Uniwersytetu w Białymstoku. Warto dodać, że wydawanie tego periodyku przypadło na okres znacznego ożywienia działalności legislacyjnej w zakresie rolnictwa, związanego początkowo z dostosowaniem polskiego prawa do prawa unijnego w celu uzyskania członkostwa, a następnie - po przyjęciu Polski do Unii Europejskiej - z objęciem tego działu gospodarki mechanizmami wspólnej polityki rolnej.

To ożywienie znalazło wyraz także w zróżnicowaniu i bogactwie problematyki artykułów publikowanych na łamach czasopisma. Treść kolejnych tomów (ostatni ukazał się w 2018 r.) świadczy o ekspansji prawa rolnego i o rozwoju nauki o tym prawie. Przedmiotem opracowań, obok tradycyjnych zagadnień tej dziedziny prawa (np. scalanie gruntów, ustrój rolny, gospodarstwo rolne, własność rolnicza, obrót gruntami rolnymi) ${ }^{42}$, były też kwestie nowe, wynikające zwłaszcza z wdrażania prawa unijnego do krajowego porządku prawnego (np. organizacja rynku rolnego, płatności bezpośrednie, rozwój obszarów wiejskich, wsparcie grup producentów rolnych) ${ }^{43}$. Układ treści każdego z tomów był podobny, uzasadniony względami merytorycznymi. Z reguły wyrażał on przejście od prezentacji kwestii o charakterze bardziej ogólnym do tych, które polegały na rozstrzyganiu szczegółowych problemów (także w formie glos). Dzięki temu „Studia” starały się połączyć wartości akademickie z praktyczna użytecznością publikacji, stając się forum dyskusji także dla szerszego grona agrarystów młodszego pokolenia.

Jednocześnie jako czasopismo Stowarzyszenia wyrażało ono szacunek i uznanie dla nestorów nauki prawa rolnego. Drugi tom z 2001 r. był dedykowany Aleksandrowi Lichorowiczowi, profesorowi Uniwersytetu Jagiellońskiego, z okazji jubileuszu 40-lecia pracy naukowej i dydaktycznej, osobie niezwykle zasłużonej dla rozwoju nauki prawa rolnego, w tym badań prawnoporównawczych oraz awansów młodej kadry. Kolejny, III tom poświęcony był uczczeniu pamięci tragicznie zmarłego Waleriana Pańki, profesora Uniwersytetu

${ }^{41}$ Ze słowa wstępnego S. Prutisa (redaktora) zamieszczonego w I tomie „Studia Iuridica Agraria", s. 7.

${ }^{42}$ Zob. np. Zieliński (2001): 226 n.; Lichorowicz (2005): 7 n.; Prutis (2005): 168 n.

${ }^{43}$ Zob. np. Bieluk, Łobos-Kotowska (2011): 294 n.; Tomkiewicz (2007): 23 n.; Król (2015): 77 n. 
Śląskiego, wybitnego uczonego, zasłużonego polityka i działacza. Wielokrotnie autorzy dedykowali swoje prace prof. Stelmachowskiemu. W 2005 r. ukazał się V tom uświetniający 80-lecie jego urodzin. Wspomnienie o Profesorze oraz publikacje poświęcone jego wkładowi w rozwój nauki prawa rolnego zostały opublikowane w 2009 r. w tomie VII, a po części także w tomie XIV z 2016 w związku z siódmą rocznica jego śmierci.

Z kolei „Przegląd Prawa Rolnego”, obecnie jedyne w Polsce czasopismo prawnorolne ${ }^{44}$, został utworzony w 2007 r. jako półrocznik Wydziału Prawa i Administracji Uniwersytetu im. Adama Mickiewicza w Poznaniu. Powinno ono, zgodnie z założeniami programowymi, dostarczyć czytelnikowi wiedzy z różnych dziedzin tej dyscypliny, służyć rozwojowi nauki o prawie rolnym, wspierać proces stanowienia prawa, a także jego stosowania w praktyce. Z tego punktu widzenia „Przegląd” bliski jest wcześniej prezentowanym czasopismom zachodnioeuropejskim. Nie zawiera on wprawdzie podtytułu, ale logo zamieszczone na okładce wyraża szerokie ujęcie prawa rolnego, obejmujące obok (tradycyjnie rozumianego) rolnictwa także prawną problematykę żywności, środowiska (w rolnictwie), obszarów wiejskich i krajobrazu wiejskiego. Łączy ono element lokalny w rozwoju tej nauki z elementem globalnym.

Układ treści został przyporządkowany realizacji wspominanych założeń programowych. Każdy numer obejmuje trzy działy: artykuły, przegląd piśmiennictwa oraz przegląd orzecznictwa. By pokazać dorobek naukowy agrarystów, zamieszcza się ponadto polską bibliografię prawnorolną (raz w roku), a także sprawozdania i informacje oraz wspomnienia. Najbardziej rozbudowany jest dział obejmujący artykuły, które prezentowane są według następującej kolejności: teoria prawa rolnego, studia i materiały z badań, międzynarodowe prawo rolnictwa, nowości unijnego prawa rolnego, dydaktyka, prawo rolne za granica, prawo rolne w praktyce i prawo rolne in statu nascendi. Aby przybliżyć polskim agrarystom dorobek nauki zagranicznej, obok recenzji i not recenzyjnych, publikowane sa również streszczenia artykułów z prezentowanych wyżej czasopism zachodnioeuropejskich. Raz w roku w ramach przeglądu orzecznictwa, oprócz glos i komentarzy, zamieszcza się także tezy orzeczeń w sprawach rolnych.

Wymieniona tematyka publikacji artykułowych wskazuje na bardzo szeroki zakres poruszanych w nich problemów. Obok tradycyjnych zagadnień prawa rolnego autorzy podejmuja kwestie nowe, dotyczące unijnego prawa rolnego czy wynikające zwłaszcza z wdrażania tego prawa do polskiego porządku prawnego (np. płatności w rolnictwie, organizacja rynków rolnych, rozwój obszarów wiejskich) ${ }^{45}$, a także tematy o charakterze innowacyjnym (np. nanotechnologia w produkcji żywności, nowa żywność, klonowanie zwierząt czy przeciwdziałanie marnowaniu żywności $)^{46}$. Artykuły publikowane w ramach „teorii prawa rolnego” służą wzmocnieniu nauki o tym prawie, określają

${ }^{44}$ Czasopismo otrzymało dofinansowanie Ministerstwa Nauki i Szkolnictwa Wyższego w ramach programu „Wsparcie dla czasopism naukowych” (2019 r.). Punktacja MNiSW - 20.

${ }^{45}$ Zob. np. Łobos-Kotowska (2007): 109 n.; Litwiniuk (2014): 45 n.; Lipińska (2018): 91 n.

46 Dla przykładu: Leśkiewicz (2013): 87 n.; Sokołowski (2018): 123 n. 
jego przedmiot i współczesne granice. Wiele publikacji zawiera postulaty co do kształtu przyszłych regulacji prawnych ${ }^{47}$, inne natomiast rozstrzygaja problemy przydatne w procesie stosowania prawa. Dzięki temu czasopismo wpływa nie tylko na rozwój nauki prawa rolnego, umocnienie jego pozycji wśród innych szczegółowych nauk prawnych, ale również jest użyteczne dla praktyki.

Zwraca uwagę coraz wyższy stopień umiędzynarodowienia „Przeglądu”. Już w 2007 r. w pierwszym numerze tego czasopisma zostały opublikowane artykuły trzech uznanych agrarystów włoskich ${ }^{48}$. Przez dłuższy czas opracowania zagraniczne były tłumaczone i ukazywały się w języku polskim. Ta praktyka ułatwiała polskim czytelnikom zapoznanie się z ich treścia, ale ograniczała dostępność za granicą. Dlatego artykuły zagraniczne od kilku lat publikuje się w języku ojczystym ich autorów (w jednym z języków kongresowych). W niektórych numerach czasopisma te opracowania stanowią istotna część pierwszego działu ${ }^{49}$, a ich autorzy wywodzą się nie tylko z krajów zachodnioeuropejskich (zwłaszcza z Niemiec, Włoch i Hiszpanii), lecz także z państw Ameryki Południowej.

Innym aspektem umiędzynarodowienia „Przeglądu” są artykuły polskich autorów publikowane w języku angielskim ${ }^{50}$. Dzięki temu krajowi agraryści włączaja się do prowadzonej w skali globalnej dyskusji o istotnych prawnych problemach rolnictwa, wyżywienia i środowiska. Wreszcie ten aspekt czasopisma znajduje wyraz w składzie Komitetu Naukowego; wchodza do niego uznani agraryści z wielu państw europejskich. Dopełnieniem sa streszczenia artykułów w języku angielskim i włoskim. Jak zatem widać, „Przegląd” łączy element lokalny w rozwoju nauki prawa rolnego z elementem globalnym, stanowi forum wymiany myśli naukowej nie tylko w skali europejskiej, ale nawet światowej.

IV. Przeprowadzone rozważania uprawniają do sformułowania kilku wniosków. Po pierwsze, czasopisma z zakresu prawa rolnego były zakładane na różnych etapach rozwoju tej gałęzi prawa. Najstarsze („Rivista di Diritto Agrario") wprowadziło do obiegu naukowego nazwę nowej materii normatywnej, przyczyniło się do wyodrębnienia prawa rolnego w systemie prawa i jej dalszego rozwoju. Kolejne z nich („Agrar- und Umweltecht”, „Revue de Droit Rural” i „Revista de Derecho Agrario y Alimentrario”) zostały utworzone w latach siedemdziesiątych i osiemdziesiątych ubiegłego wieku, by wzmocnić naukę prawa rolnego i jej oddziaływanie na praktykę stanowienia i stosowania prawa.

Taki sam cel można też przypisać czasopismom założonym w Polsce w latach dziewięćdziesiątych. Zmiany ustrojowe po 1989 r. i związane z nimi kształtowanie ustawodawstwa rolnego stanowiły duże wyzwanie dla nauki prawa rolnego. Jednakże ograniczony krąg autorów przesądził, jak już powiedzia-

\footnotetext{
${ }^{47}$ W szczególności: Lichorowicz (2010): 63 n.; Suchoń (2017): $191 \mathrm{n}$.

48 Costato (2007): 11 n.; Germanò (2007): 43 n.; Adornato (2007): 209 n.

49 Zob. np. PPR 2016, nr 2; 2018, nr 1, 2018, nr 2; 2019, nr 1.

${ }^{50}$ Zob. np. Wojciechowski (2016): 33 n.; Budzinowski (2019): 11 n.; Kapała (2020): 65 n.
} 
no, o zaprzestaniu ich wydawania. Znaczne wzmocnienie kadry prawników agrarystów, także ożywienie działalności legislacyjnej wynikające z potrzeby dostosowania polskiego prawa rolnego do standardów europejskich i późniejsze członkostwo Polski w Unii Europejskiej uzasadniały powołanie do życia nowego czasopisma („Studia Iuridica Agraria”), będącego organem Polskiego Stowarzyszenia Prawników Agrarystów. Siedem lat później został utworzony, funkcjonujący do dzisiaj, „Przegląd Prawa Rolnego”.

Po drugie, wbrew sugestiom prima facie, zakres tematyczny publikacji $\mathrm{w}$ czasopismach prawnorolnych bynajmniej nie jest waski. Ulegał on rozszerzeniu wraz z ekspansja prawa rolnego. Wyrazem tej tendencji było dodanie podtytułu w periodyku włoskim, wskazującego na przedmiot zainteresowania (,rolnictwo, wyżywienie, środowisko”), także w periodyku francuskim (dodano nadto „obszary wiejskie”), uzupełnienie nazwy czasopisma w Niemczech o prawo środowiska czy - jak w periodyku hiszpańskim - odniesienie się już w tytule do prawa rolnego i prawa żywnościowego. Czasopisma prawnorolne wydawane w obecnym wieku w Polsce również odzwierciedlają tę tendencję; obejmują problematykę tradycyjnego prawa rolnego, rolno-żywnościową i rolno-środowiskową. Nie odbiegają one zatem od zakresu tematycznego periodyków zachodnioeuropejskich.

Po trzecie, uwzględnianie ekspansji prawa rolnego wpłynęło na rozszerzenie kręgu adresatów-czytelników czasopism prawnorolnych. Zawierają one opracowania, które mogą zainteresować różne podmioty występujące w tzw. łańcuchu żywnościowym, od producenta rolnego do konsumenta żywności, jak również te wszystkie instytucje, które zajmują się stanowieniem i stosowaniem prawa rolnego. Łączy się z tym misja czasopisma określona już w założeniach programowych lub wynikająca $\mathrm{z}$ treści publikowanych opracowań. Jest nią z reguły umocnienie nauki prawa rolnego oraz wsparcie praktyki stanowienia i stosowania prawa. Problem stanowi wyważenie pewnych proporcji między wartościami akademickimi publikacji a ich użytecznością praktyczną. Ta ostatnia wysuwa się na pierwszy plan w czasopiśmie niemieckim i francuskim, ale nie jest pomijana w periodyku włoskim i hiszpańskim. Mimo braku otwartego dostępu do zamieszczanych tam opracowań, zainteresowanie czytelników jest znaczne ('świadczy o tym olbrzymi nakład francuskiego „Revue de Droit Rural”).

Również współczesne polskie czasopisma starają się znaleźć równowagę między wartościami akademickimi i praktycznymi. Eksponowanie w „Przeglądzie Prawa Rolnego" rozważań o charakterze teoretycznym wynika z zamiaru ograniczenia pewnego zapóźnienia w rozwoju nauki prawa rolnego i potrzeby uaktualnienia jej teoretycznych podstaw w warunkach objęcia polskiego rolnictwa wspólną polityką rolna. Jest to wszakże wspólna płaszczyzna badań agrarystów ze wszystkich państw członkowskich Unii Europejskiej. W tym zakresie nauka prawa rolnego w Polsce osiagnęła znaczący postęp ${ }^{51}$. Cieszy zaś fakt powoływania się praktyków na artykuły publikowane w „Przeglądzie”. Świadczy on o wpływie proponowanych w nich rozstrzygnięć na życie społeczne i gospodarcze.

${ }^{51}$ Bliżej Budzinowski (2019): 11 n. 
Po czwarte, oczywiste jest, że we wszystkich prezentowanych czasopismach prawnorolnych dominują opracowania dotyczące prawa krajowego, po części unijnego prawa rolnego, które przecież stanowi element prawa wewnętrznego każdego państwa członkowskiego. Taka bowiem jest swoistość badań prowadzonych w naukach prawnych. W nauce prawa rolnego poruszane sa jednak coraz częściej problemy o wymiarze globalnym (np. dotyczące bezpieczeństwa żywnościowego, przeciwdziałania degradacji gruntów rolnych czy zmianom klimatu). Znajdują one wyraz w treści prezentowanych czasopism, których językiem jest przede wszystkim język państwa, w którym są one wydawane. W ten sposób bowiem realizowane są cele owych periodyków, publikowanych $\mathrm{z}$ reguły w wydawnictwach o charakterze komercyjnym.

W tym kontekście „Przegląd Prawa Rolnego” wyróżnia się stopniem umiędzynarodowienia nie tylko $\mathrm{z}$ racji podejmowania tematów o charakterze regionalnym i globalnym, ale również ze względu na liczne publikacje autorów zagranicznych w ich ojczystych językach, a także autorów polskich z reguły w języku angielskim. Wpływa to oczywiście na stopień cytowalności czasopisma, a zainteresowanie artykułami w „Przeglądzie” widoczne jest w różnych państwach świata. Wszelako, by zachować użyteczność publikacji dla polskiego czytelnika, trzeba utrzymać też pewną równowagę między opracowaniami zagranicznymi i polskimi oraz między publikacjami w językach obcych a tymi w języku polskim.

Po piąte, czasopisma prawnorolne zajmują ważne miejsce w rozwoju nauki prawa rolnego. Służą jej wzmocnieniu, a jednocześnie świadczą o jej pozycji, stopniu rozwoju oraz potencjale kadry prawników agrarystów. Periodyki zachodnioeuropejskie z tej dziedziny mogą pochwalić się zbliżającym się jubileuszem stulecia (jak „Rivista di Diritto Agrario”), jubileuszem pięćdziesięciolecia (czasopismo niemieckie i francuskie) czy kilkoma dziesiątkami lat aktywności wydawniczej (czasopismo hiszpańskie). Mają one swoich stałych licznych czytelników, często profesjonalnie związanych ze stosowaniem prawa rolnego, szerokie grono autorów (nie tylko naukowców, ale też praktyków) i źródło finansowania (także z prenumeraty). Dlatego ich przyszłość nie jest zagrożona.

$\mathrm{Na}$ tym tle niezbyt dobrze wypadaja czasopisma prawnorolne w Polsce. Charakteryzuje je krótki okres funkcjonowania na rynku wydawniczym, co w przeszłości można było tłumaczyć niezbyt liczną kadrą prawników agrarystów (a zatem również wąskim gronem autorów). Obecnie sytuacja w nauce prawa rolnego jest zgoła inna, aczkolwiek i w tym zakresie jest jeszcze wiele do zrobienia; na kilku uniwersytetach brakuje katedr (zakładów) prawa rolnego, a nawet osób, które zajmowałyby się uprawianiem nauki o tym prawie. Zagrożenie dla przyszłości „Przeglądu Prawa Rolnego” może wynikać z kierowania przez autorów artykułów z zakresu prawa rolnego do druku do innych, wyżej punktowanych czasopism. W każdym razie zaniechanie wydawania „Przeglądu” oznaczałoby utratę możliwości prowadzenia dyskusji w wymiarze nie tylko krajowym, ale także międzynarodowym. Spowodowałoby to, jak można sądzić, osłabienie nauki prawa rolnego w Polsce i stopnia jej umiędzynarodowienia, jak też oddziaływania na praktykę stanowienia i stosowania prawa. 
Abramowitch, L. (2016). L'alimentation saine dans la nouvelle politique de l'alimentation: à quel «sain» se vouer? Revue de Droit Rural 444: 19-23.

Adornato, F. (2004). Di che cosa parliamo quando parliamo di agricultura? Agrucultura Istituzioni Mercati 1: 5-9.

Adornato, F. (2007). Od kontraktu rolnego do kontraktualizacji programowanej. Przegląd Prawa Rolnego 1: 209-223.

Alabrese, M. (2016). TTIP e agroalimentare. Prime rifflessioni a margine delle proposte dell'Unione Europea nella negoziazione della Trans-atlantic Trade and Investment Partnership. Rivista di Diritto Agrario 2: 210-242.

Ballarin Marcial, A. (1984). Dal diritto agrario al diritto agro-alimentare. Rivista di Diritto Agrario 2: 204-223.

Ballarin Marcial, A. (1985). Derecho agrario, Derecho alimentario, Derecho agroalimentario. Revista de Derecho Agrario y Alimentario 1: 7-13.

Bieluk, J., Łobos-Kotowska, D. (2011). Kwoty mleczne jako przedmiot obrotu - wybrane zagadnienia. Studia Iuridica Agraria 9: 294-305.

Blumann, C. (2013). La politique agricole commune face aux nouveaux défis planétaires et européens. Revue de Droit Rural 416: 17-23.

Błażejczyk, M. (1991). Polityczno-legislacyjny dysonans w dążeniu do zintegrowania polskiego rolnictwa z Europejską Wspólnotą Gospodarcza. Prawo Rolne 1: 5-17.

Błażejczyk, M. (1993). Stowarzyszenie Polski ze Wspólnotami Europejskimi i jego polityczno-prawne implikacje w sferze rolnictwa. Prawo Rolne 3: 5-14.

Bolognini, S. (2018). La Comunicazione della Commissione Europea "Il futuro dell'alimentazione e dell'agricoltura". Rivista di Diritto Agrario 1: 110-135.

Booth, J. (2020). 50 Jahre Zeitschrift für Agrarrecht/Agrar- und Umweltrecht - ein perönlicher Rückblick. Agrar- und Umweltrecht 9: 321.

Bourges, L.A. (2015). Agricultura y urbe: ventajas y desafios frente a la necesidad de un desarrollo integral. Revista de Derecho Agrario 66: 51-70.

Brebbia, F.P. (1996). Szranki prawa rolnego. Prawo Rolne 3: 23-36.

Brebbia, F.P. (1999). Unidad economica la minima unidad de cultivo. Acta Iuridica Agraria I: $45-71$

Budzinowski, R. (2012). O potrzebie rozwoju nauki prawa rolnego. Przegląd Prawa Rolnego 1: $13-32$.

Budzinowski, R. (2019). The science of agricultural law in Poland. Reflections against the background of Western European science. Przegląd Prawa Rolnego 2: 11-30.

Busse, Ch. (2015). Das neue Agrarmerketrecht der GAP-Reform 2014/2017 - Zur Ablösung der Verordung (EG) Nr. 1234/2007 durch die Verordung (EU) Nr. 1308/2013. Agrar-und Umweltrecht 9: 321-329.

Carrozza, A. (1986). Il programma scientifico del diritto agrario a quindici anni dal duemila. Rivista di Diritto Agrario 1: 324-352.

Carrozza, A. (2001). Droit agraire comparé: premisses historiques et methodologiques, [w:] A. Carrozza, Scritti di diritto agrario. Milano: 691-704.

Cosialls Ubach, A.M. (2017). La agricultura familiar y el "land grabbing" ante la función social de la propriedad agraria y la nueva reforma de la PAC. Revista de Derecho Agrario 71: 83-94.

Costato, L. (1987). Rapporti tra diritto agrario e ambientale. Rivista di Diritto Agrario 3: 146-161.

Costato, L. (1992). Autonomia wspólnotowego prawa rolnego. Prawo Rolne 4: 5-26.

Costato, L. (2003). Dal diritto agrario al diritto agroalimentare, [w:] E. Rook Basile, A. Germanò (red.), Agricoltura e alimentazione tra diritto, comunicazione e mercato. Atti del convegno „Gian Gastone Bolla”, Firenze 9-10 novembre 2001. Milano: 324-343.

Costato, L. (2007). Wpływ wspólnotowego prawa rolnego na prawo rolne wewnętrzne. Przegląd Prawa Rolnego 1: 12-25.

Costato, L., Casadei, E. (2000). Il diritto agrario nell'anno 2000. Rivista di Diritto Agrario 1: 3-22.

Cristiani, E. (2008). Le riviste agraristiche italiane e i nuovi contenuti del diritto agrario. Rivista di Diritto Agrario 4: 464-479.

D'Addezio, M. (1999). L'incidenza delle norme di carattere ambientale sul diritto agrario. Rivista di Diritto Agrario 2: 177-198. 
De la Cuesta Sáenz, J.M. (2016). Homenaje en memoria de don Alberto Ballarín Marcial. Asociación Española de Derecho Agrario. Revista de Derecho Agrario y Alimentario 69: 7-11.

Foyer, J. (2010). Le droit rural : nouveaux horizons. Revue de Droit Rural 384: 1-2.

Foyer, J. (2012). Quelques remarques d'actualité sur la définition de l'activité agricole. Revue de Droit Rural 404: 1-2.

Gadbin, D. (2012). Les aides de la PAC aux plus démunis: une fin programmée. Revue de Droit Rural 401: 1-2.

Galloni, G. (2000). Nuovi confini del diritto agrario fra il diritto comunitario e il diritto ambientale. Rivista di Diritto Agrario 3: 390-411.

Germanò, A. (2007). Reforma Wspólnej Polityki Rolnej w 2003 r. i reżim płatności jednolitej. Przegląd Prawa Rolnego 1: 43-56.

Germanò, A. (2017). L’istituto di Dirito Agrario Internazionale e Comparato: la storia. Napoli.

Gil Adrados, P. (2016). Reflexiones sobre la mundalización y la falta de alimentos. Revista de Derecho Agrario y Alimentario 69: 79-102.

Giorgianni, M. (1964). Il diritto agrario tra il passato e l'avvenire. Rivista do Diritto Agrario 1: $21-43$.

Goldoni, M. (2019). Integrazione dell'oggetto con ambiente e alimentazione. Diritto Agroalimentare 1: 19-35.

Hudault, J. (1991). Ewolucja stosunku między gospodarstwem rolnym i jego własnością w prawie francuskim. Prawo Rolne 1: 19-33.

Irti, N. (1977). Sviluppo storico e posizione sistematica del diritto agrario italiano. Rivista di Diritto Agrario 3: 472-480.

Jannarelli, A. (2020). Il mercato agro-alimentare europeo. Diritto Agroalimentare 2: 309-345.

Kapała, A. (2020). Legal status of direct sales of agricultural and food products in the legislation of selected EU Member States. Przegląd Prawa Rolnego 1: 65-77.

Kroeschel, K. (1965). Was ist Agrarrecht? Recht der Landwirtschaft 17: 277-279.

Król, M.A. (2015). Nowe rozwiązania prawne w zakresie płatności w ramach systemów wsparcia bezpośredniego. Studia Iuridica Agraria 13: 77-100.

Krüger, W., List, M. (2017). Aktuelle Entwicklungen zur Vereinfachung der Gemeinsamen Agrarpolitik - Ein Zwischenstand. Agrar- und Umweltrecht 2: 41-44.

Leśkiewicz, K. (2013). Prawne aspekty nanotechnologii w produkcji żywności i materiałów przeznaczonych do kontaktów z żywnością. Przegląd Prawa Rolnego 2: 87-105.

Lichorowicz, A. (2005). Regulacja obrotu gruntami rolnymi według ustawy z 11 kwietnia 2003 roku o kształtowaniu ustroju rolnego na tle ustawodawstwa agrarnego Europy Zachodniej. Studia Iuridica Agraria 4: 9-30.

Lichorowicz, A. (2010). Potrzeba prawnego uregulowania dzierżawy rolnej w Polsce (na podstawie doświadczeń krajów Unii Europejskiej. Przegląd Prawa Rolnego 2: 63-78.

Lipińska, I. (2018). Wpływ rozporządzenia UE nr 2017/2393 na prawną regulację rynku mleka i przetworów mlecznych. Przegląd Prawa Rolnego 1: 91-101.

Litwiniuk, P. (2014). Z problematyki nadużycia prawa przez beneficjenta Wspólnej Polityki Rolnej. Przegląd Prawa Rolnego 2: 45-63.

Łobos-Kotowska, D. (2007). Płatności do gruntów rolnych i płatność cukrowa - wybrane zagadnienia proceduralne. Przegląd Prawa Rolnego 2: 110-123.

Martínez, J. (2010). Die Zukunft der Agrarbeihilfen. Agrar- und Umweltrecht 9: 261-264.

Mögele, F., Rusu, J.E. (2018). Die Vorschläge der Kommission für die Gemeinsame Agrarpolitik nach 2020. CEDR Journal of Rural Law 2: 9-16.

Nies, V. (2020). 50 Jahre Zeitschrift für Agrarrecht/Agrar- und Umweltrecht - ein persönlicher Rückblick. Agrar-und Umweltrecht 9: 322-324.

Orlando, P.R. (1991). Desarrollo sostenible, integración y trabajo rural frente a la globalización. Acta Iuridica Agraria 1: 169-176.

Paiva Pereira, L. de (2015). Brasil and Environmental Protection. CEDR Journal of Rural Law 1: 96-99.

Paliwoda, J. (1996). Podstawowy dorobek piśmienniczy z zakresu prawa rolnego w czterdziestoleciu Instytutu Nauk Prawnych PAN (1956-1996). Prawo Rolne 4: 12-34.

Peignot, B. (2016). De l'usage du recrit en matiére de contrôle des structures. Revue de Droit Rural 442: 13-15. 
Prutis, S. (2005). Kształtowanie ustroju rolnego - potrzeba nowej regulacji. Studia Iuridica Agraria 5: $168-184$.

Prutis, S. (red.) (1998). Polskie prawo rolne u progu Unii Europejskiej. Białystok.

Romagnoli, E. (1972). Giangastona Bolla, la sua opera, la sua rivista. Rivista di Diritto Agrario 1.

Sánchez Hernández, A. (2000). El derecho agrario en Espaňa: perspectiva historica y prospectiva. Revista de Derecho Agrario i Alimentario 37: 1107-1138.

Sirsi, E. (1986). La «cultura» delle Riviste e la Rivista di diritto agrario, [w:] Metodi e contenuti del diritto agrario moderno. Milano: 420-434.

Sokołowski, Ł.M. (2018). Nowa żywność a współczesne wyzwania żywnościowe - wybrane aspekty prawne. Przegląd Prawa Rolnego 1: 123-132.

Spoto, G. (2019). Global and local dimensions of farms. CEDR Journal of Rural Law 2: 9-15.

Suchoń, A. (2017). Uwagi na tle projektu ustawy o spółdzielniach rolników. Przegląd Prawa Rolnego 2: 191-208.

Tomkiewicz, E. (2007). Polityka rozwoju obszarów wiejskich na lata 2007-2013 (perspektywy na tle dotychczasowej ewolucji ustawodawstwa). Studia Iuridica Agraria 6: 23-38.

Trebeschi, C. (2011). Primi appunti per una storia della Rivista di Diritto Agrario. In memoria di don Carlo Zaccaro (1922-2010). Rivista di Diritto Agrario 2: 242-262.

Wojciechowski, P. (2016). Administrative liability of a farmer acting as food business operator. Przegląd Prawa Rolnego 1: 33-48.

Zieliński, A. (2001). Scalanie gruntów - przeszłość czy zadanie przyszłości. Studia Iuridica Agraria $2: 226-236$.

\title{
AGRICULTURAL LAW PERIODICALS IN POLAND: REFLECTIONS BASED ON A COMPARISON WITH WESTERN EUROPEAN COUNTERPARTS
}

\author{
Sum mary
}

The aim of this paper is to evaluate Polish agricultural law periodicals in comparison with their Western European counterparts. In particular, the evaluation takes into account the mission of the periodicals, their thematic scope, the layout and language of the texts published, and the circle of their addressees-readers. With consideration given to the length of time that such periodicals have been on the publishing market and their publication output, the Italian context is the first to be taken into account, before attention turns to German, French, and Spanish periodicals. The author concludes that agricultural law periodicals were established at different stages in the development of this branch of law. The oldest one (Rivista di Diritto Agrario) brought the name of this new normative matter into scientific circulation, and subsequently contributed to both the separation of agricultural law in the system of law and its further development. Other periodicals (Agrar- und Umweltrecht, Revue de Droit Rural and Revista de Derecho Agrario y Alimentrario) were established in the 1970s and 1980s, with a view to strengthening the science of agricultural law and its influence on the practice of law-making and application. In this light, Polish agricultural law periodicals look somewhat inferior, as they are characterized by a short period of functioning on the publishing market. The future of the periodical Przeglad Prawa Rolnego (Agricultural Law Review), the only agricultural law journal in Poland, is under threat, due to the fact that authors now tend to submit articles on agricultural law to other, more highly-ranked journals.

Keywords: agricultural law; science of agricultural law; agricultural law journals; Przeglad Prawa Rolnego / Agricultural Law Review 